\title{
PERENCANAAN KEBIJAKAN PERAWATAN MESIN CORAZZA FF100 PADA LINE 3 PT XYZ DENGAN METODE RELIABILITY CENTERED MAINTENANCE (RCM) II
}

\author{
${ }^{1}$ Ully Tri Kirana, ${ }^{2}$ Judi Alhilman, ${ }^{3}$ Sutrisno \\ 1,2,3 Prodi S1 Teknik Industri, Fakultas Rekayasa Industri, Universitas Telkom \\ ${ }^{1}$ ullytrikirana@students.telkomuniversity.ac.id, ${ }^{2}$ judi.alhilman@gmail.com, ${ }^{3}$ sutrisno_mr@yahoo.com
}

\begin{abstract}
Abstrak-PT XYZ merupakan produsen yang bergerak dalam bisnis keju. Meskipun telah menerapkan kegiatan preventive maintenance, frekuensi kerusakannya masih tinggi menyebabkan terhambatnya kelancaran proses produksi serta mengindikasikan nilai keandalannya kecil. Oleh karena itu perlu dilakukan analisis kegiatan perawatan yang tepat sesuai dengan karakteristik kerusakan serta interval waktu kegiatan perawatan pada mesin Corazza FF100 dengan analisis Reliability Centered Maintenance (RCM) II yang menekankan pada karakteristik keandalan (reliability). Melakukan identifikasi risiko yang dipetakan dalam risk matrix. Tahapan dalam RCM yaitu pengukuran kualitatif dengan membuat Failure Mode and Effect Analysis (FMEA) untuk mengidentifikasi penyebab serta efek terjadinya kegagalan item. Untuk mengetahui konsekuensi yang ditimbulkan dilakukan klasifikasi berdasarkan Logic Tree Analysis (LTA) kemudian pemilihan tindakan kegiatan perawatan. Tahap selanjutnya yaitu pengukuran kuantitatif dengan melakukan pengumpulan data kerusakan dan data perbaikan untuk mendapatkan interval waktu perawatan. Maintainable item pada mesin Corazza FF100 berjumlah 27. Berdasarkan metode Reliability Centered Maintenance (RCM) didapatkan 67 kegiatan perawatan. Terdapat 17 scheduled discard task, 15 scheduled restoration task, 31 scheduled on condition dan 4 failure finding. Penentuan interval waktu perawatan berdasarkan kebijakan perawatannya dengan mempertimbangkan karakteristik kerusakan dan biaya perawatan.
\end{abstract}

Kata kunci: preventive maintenance, reliability centered maintenance, risk matrix

\section{PENDAHULUAN}

Kegiatan perawatan mesin berguna untuk menjaga, memelihara, mempertahankan, mengembangkan dan memaksimalkan kinerja mesin untuk dapat beroperasi sesuai dengan fungsinya dan tersedia saat akan digunakan. PT XYZ telah menerapkan kegiatan perawatan yang terbagi dalam dua kegiatan yaitu perawatan pencegahan (preventive maintenance) dan perawatan perbaikan (corrective maintenance). Preventive maintenance dilakukan pada interval waktu satu bulan, tiga bulan, enam bulan, dua belas bulan, dan 24 bulan. Selain itu preventive maintenance juga dilakukan harian dan mingguan untuk memeriksa kondisi mesin. Kegiatan corrective maintenance disebabkan karena kegagalan pada mesin atau komponen yang terjadi secara mendadak. Meskipun PT XYZ telah menerapkan kegiatan perawatan secara preventive maintenance, namun frekuensi kerusakannya masih tinggi. Berikut Gambar 1 frekuensi kerusakan pada bulan Januari 2013 sampai bulan Desember 2014. Line 3 memiliki frekuensi kerusakan yang paling tinggi sehingga penelitian ini difokuskan pada Line 3.

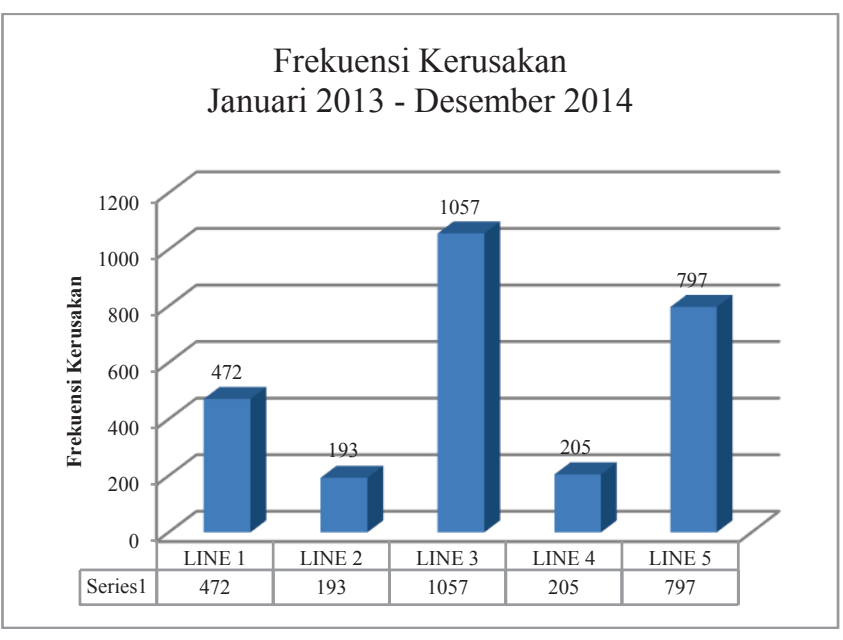

Gambar 4 Frekuensi Kerusakan (Januari 2013 - Desember 2014)

Frekuensi kerusakan yang tinggi dapat menyebabkan terhambatnya kelancaran proses produksi yang mengakibatkan tidak tercapainya target produksi. Hal ini dapat menimbulkan loss production sehingga akan mengakibatkan kerugian pada perusahaan. Tabel I adalah data loss production Line 3 pada bulan April s.d. Desember 2014. Proses produksi di Line 3 saling terintegrasi. Jadi apabila salah satu mesin mengalami breakdown, maka proses produksi akan berhenti. Oleh karena itu, mesin yang mengalami frekuensi kerusakan paling tinggi perlu dilakukan perawatan secara tepat sesuai dengan karakteristik kerusakannya agar mesin dapat menjalankan fungsinya dan dapat mencapai target produksi dalam jumlah yang sesuai.

Berdasarkan Tabel II, mesin Corazza FF100 memiliki persentase frekuensi kegagalan yang paling tinggi. Frekuensi kerusakan yang tinggi mengindikasikan bahwa nilai reliability atau keandalannya kecil. Oleh karena itu, perlu dilakukan 
analisis kegiatan perawatan yang tepat sesuai dengan karakteristik kerusakan serta interval waktu kegiatan perawatan optimum yang mempertimbangkan pada biaya perawatan yang paling minimum pada mesin Corazza FF100 dengan dilakukan analisis Reliability-Centered Maintenance (RCM) II yang menekankan pada karakteristik keandalan (reliability). RCM adalah suatu proses yang digunakan untuk menentukan apa yang harus dilakukan untuk menjamin agar sembarang asset fisik dapat berlangsung terus memnuhi fungsi yang diharapkan dalam konteks operasinya saat ini [1].

TABEL I

DATA LOSS PRODUCTION LINE 3 BULAN APRIL-DESEMBER 2014

\begin{tabular}{|l|l|}
\hline Bulan & Loss Production \\
\hline April & $11.48 \%$ \\
\hline Mei & $44.71 \%$ \\
\hline Juni & $16.38 \%$ \\
\hline Juli & $16.71 \%$ \\
\hline Agustus & $31.33 \%$ \\
\hline September & $26.30 \%$ \\
\hline Oktober & $22.17 \%$ \\
\hline November & $26.72 \%$ \\
\hline Desember & $5.47 \%$ \\
\hline
\end{tabular}

TABEL II

FREKUENSI KERUSAKAN MESIN PADA LINE 3

\begin{tabular}{|l|l|l|l|l|l|}
\hline \multirow{2}{*}{ Mesin } & \multicolumn{2}{|l|}{$\begin{array}{l}\text { Frekuensi } \\
\text { Kerusakan }\end{array}$} & \multirow{2}{*}{ Jumlah } & Persentase & $\begin{array}{l}\text { Persentase } \\
\text { Kumulatif }\end{array}$ \\
\cline { 2 - 3 } & $\mathbf{2 0 1 3}$ & $\mathbf{2 0 1 4}$ & & & $81.17 \%$ \\
\hline Corazza FF100 & 208 & 187 & 395 & $37.37 \%$ & $92.53 \%$ \\
\hline Conveyor & 67 & 53 & 120 & $11.35 \%$ & $95.46 \%$ \\
\hline Stephan Kettle & 18 & 13 & 31 & $2.93 \%$ & $97.07 \%$ \\
\hline Steam Transfer & 6 & 11 & 17 & $1.61 \%$ & $98.49 \%$ \\
\hline Coding & 3 & 12 & 15 & $1.42 \%$ & $99.15 \%$ \\
\hline $\begin{array}{l}\text { Grinding } \\
\text { Kustner }\end{array}$ & 4 & 3 & 7 & $0.66 \%$ & $99.62 \%$ \\
\hline Firstamp Pump & 3 & 2 & 5 & $0.47 \%$ & $99.91 \%$ \\
\hline Check weigher & 2 & 1 & 3 & $0.28 \%$ & $100.00 \%$ \\
\hline Metal Detector & 1 & 0 & 1 & $0.09 \%$ & \\
\hline Total & & & $\mathbf{1 0 5 7}$ & $100 \%$ & \\
\hline
\end{tabular}

\section{METODE PENELITIAN}

System Breakdown Structure dilakukan untuk menganalisis dan mendokumentasikan sistem dan subssitem hingga maintainable item sehingga dapat diketahui struktur level secara jelas pada mesin Corazza FF100. Melakukan identifikasi risiko berdasarkan pada bahaya yang ada akibat kegagalan maintainable item yang dipetakan dalam risk matrix.

Pengukuran kualitatif dilakukan dengan pembuatan Failure Mode and Effect Analysis (FMEA). FMEA dilakukan untuk mengidentifikasi kegagalan komponen yang pendefinisiannya meliputi penyebab terjadinya kegagalan serta efek dari kegagalan komponen tersebut memenuhi standar kinerjanya. Untuk mengetahui konsekuensi yang ditimbulkan oleh masing-masing penyebab terjadinya kegagalan pada komponen dilakukan klasifikasi menggunakan Logic Tree Analysis (LTA). Selanjutnya, dilakukan pemilihan tindakan kegiatan perawatan (maintenance task) yang sesuai berdasarkan karakteristik kegagalan komponen.

Pengukuran kuantitatif dilakukan dengan melakukan pengumpulan data mengenai data kerusakan dan data perbaikan untuk masing-masing komponen. Untuk mendapatkan nilai MTTF dan MTTR, dilakukan plotting data untuk mengetahui distribusi data yang sesuai dari data kerusakan dan data perbaikan. Dari distribusi data yang sesuai tersebut, kemudian ditentukan parameter distribusi data kerusakan dan data perbaikan yang digunakan untuk menghitung nilai MTTF dan MTTR. MTTF adalah waktu rata-rata terjadinya kerusakan sedangkan MTTR adalah waktu rata-rata yang diperlukan untuk melakukan perbaikan terhadap suatu item yang mengalami kerusakan. Interval waktu perawatan ditentukan berdasarkan kegiatan perawatannya yang mempertimbangkan konsekuensi kegagalan, MTTF dan biaya perawatan.

TABEL III

FAILURE MODE AND EFFECT ANALYSIS

\begin{tabular}{|c|c|c|c|c|c|c|c|c|c|}
\hline \multirow{2}{*}{\multicolumn{2}{|c|}{$\begin{array}{c}\text { Machine } \\
\text { Unit }\end{array}$}} & \multicolumn{8}{|c|}{ Corazza FF100 } \\
\hline & & Fille & Unit & & & & & & \\
\hline \multicolumn{2}{|c|}{ Subunit } & \multicolumn{8}{|c|}{ Dosing Subunit } \\
\hline No & $\begin{array}{l}\text { Item } \\
\text { Name }\end{array}$ & & Function & Func & tional Failure & & Failure Mode & Cause & Failure Effect \\
\hline \multirow[t]{2}{*}{1} & \multirow[t]{2}{*}{ Valve } & \multirow[t]{2}{*}{1.1} & \multirow{2}{*}{$\begin{array}{l}\text { Membuat aliran } \\
\text { angin hanya } \\
\text { mengalir kesatu } \\
\text { arah saja atau } \\
\text { agar tidak terjadi } \\
\text { reversed } \\
\text { flow/back flow }\end{array}$} & \multirow{2}{*}{\multicolumn{2}{|c|}{$1.1 .1 \begin{array}{c}\text { Gagal membuat } \\
\text { aliran angin } \\
\text { mengalir kesatu } \\
\text { arah saja atau } \\
\text { terjadi reversed } \\
\text { flow/back flow }\end{array} \mid$}} & 1 & Leakage & $\begin{array}{l}\text { - Kedudukan valve tidak rapat pada } \\
\text { seatingnya } \\
\text { - Getas } \\
\text { - Kesalahan pemasangan } \\
\text { - Wear } \\
\text { - Dynamic instability } \\
\end{array}$ & Valve terbakar \\
\hline & & & & & & 2 & $\begin{array}{l}\text { Gagal membuka dan } \\
\text { menutup }\end{array}$ & Valve stem rusak & Poor valve response \\
\hline
\end{tabular}




\section{HASIL DAN PEMBAHASAN}

Pengukuran kualitatif dilakukan dengan pembuatan Failure Mode and Effect Analysis (FMEA) terdapat pada Tabel III untuk mengidentifikasi kegagalan komponen yang pendefinisiannya meliputi penyebab terjadinya kegagalan serta efek dari kegagalan komponen tersebut memenuhi standar kinerjanya.

Data Time to Repair merupakan data yang menunjukkan waktu yang digunakan untuk perbaikan (repair) suatu maintainable item, sedangkan data Time to Failure merupakan data yang menunjukkan waktu terjadinya kegagalan suatu maintainable item. Penelitian ini mengabaikan waktu persiapan dan/atau penundaan serta waktu menunggu dan/atau penundaan sehingga waktu perbaikan (TTR) sama dengan downtime. Untuk mengukur kesesuian distribusi dari data Time to Repair dan data Time to Failure untuk setiap maintainable item terhadap distribusi normal, distribusi eksponensial dan distribusi weibull dilakukan uji Anderson Darling.

Perhitungan Mean Time To Repair dan Mean Time To Failure berdasarkan pada distribusi yang mewakili setiap maintainable item. Setelah diketahui distribusi yang mewakili, dilakukan penentuan parameter dengan dibantu software AvSim+ 9.0. Apabila maintainable item berdistribusi normal atau eksponensial maka,

MTTR atau $\mathrm{MTTF}=\mu$

Namun, apabila maintainable item berdistribusi weibull dapat dihitung dengan menggunakan rumus berikut:

MTTR atau $\mathrm{MTTF}=\eta \cdot \Gamma\left(1+\frac{1}{\beta}\right)$

Nilai $\Gamma\left(1+\frac{1}{\beta}\right)$ didapat dari $\Gamma(\mathrm{x})=$ tabel fungsi Gamma.

Perhitungan karakteristik reliability meliputi fungsi kepadatan peluang $\mathrm{f}(\mathrm{t})$ yang menunjukkan peluang setiap kejadian terhadap waktu, fungsi distribusi kumulatif $\mathrm{F}(\mathrm{t})$ menunjukkan peluang kumulatif kegagalan item selama waktu $\mathrm{T}$, fungsi keandalan $\mathrm{R}(\mathrm{t})$ menunjukkan peluang item dapat melakukan fungsinya dalam rentang waktu $\mathrm{T}$ tanpa terjadi kegagalan dan fungsi laju kerusakkan $\lambda(t)$ menunjukkan perubahan laju kerusakan terhadap waktu. Berikut adalah contoh perhitungan karakteristik reliability untuk maintainable item motor yang berdistribusi normal dengan parameter dari data TTF, $\mu=329.58$ dan $\sigma=184.13$ dengan $\mathrm{t}=300$.

1. Fungsi kepadatan peluang

$$
\begin{aligned}
& f(t)=\frac{1}{\sigma \cdot \sqrt{2 \pi}} \cdot e^{\left\{\frac{-(\mathrm{t}-\mu)^{2}}{2 \sigma^{2}}\right\}} \\
& f(300)=\frac{1}{184.13 \times \sqrt{2 \times 3.14}} e^{-\frac{1}{2}\left(\frac{(300-329.58)^{2}}{184.13^{2}}\right)} \\
& f(300)=0.00214
\end{aligned}
$$

2. Fungsi distribusi kumulatif

$$
\begin{aligned}
& F(t)=\Phi\left(\frac{t-\mu}{\sigma}\right) \\
& F(300)=\Phi\left(\frac{300-329.58}{184.13}\right) \\
& F(300)=0.43619=43.619 \%
\end{aligned}
$$

Nilai $\Phi(z)$ didapat dari tabel normal

3. Fungsi keandalan

$$
\begin{aligned}
& R(t)=1-\Phi\left(\frac{t-\mu}{\sigma}\right) \\
& R(300)=1-\Phi\left(\frac{300-329.58}{184.13}\right) \\
& R(300)=0.56381=56.381 \%
\end{aligned}
$$

Nilai $\Phi(z)$ didapat dari tabel normal

4. Fungsi laju kerusakkan

$$
\lambda(t)=\frac{f(t)}{R(t)}=\frac{\frac{1}{\sqrt{2 \pi \sigma}} \cdot e^{\left\{\frac{-(t-\mu)^{2}}{2 \sigma^{2}}\right\}}}{1-\phi\left(\frac{t-\mu}{\sigma}\right)}
$$

$\lambda(300)=0.00379$

Nilai $\Phi(\mathrm{z})$ didapat dari tabel normal

Penentuan kebijakan perawatan yang sesuai ditentukan berdasarkan fungsi, kegagalan fungsional, modus kegagalan, efek kegagalan, dan konsekuensi kegagalan masing-masing item, sehingga setiap item akan memiliki maintenance task yang berbeda-beda. RCM menghasilkan preventive task berupa schedule restoration, schedule discard, dan schedule on condition. Selain itu, RCM juga menghasilkan default action berupa schedule failure finding dan juga run to failure.

Perhitungan interval waktu perawatan optimal untuk scheduled discard task dan scheduled restoration task dilakukan dengan bantuan software Reliasoft RCM++. Data yang diperlukan yaitu distribusi TTF serta parameternya, biaya perawatan korektif setiap kejadian (unplanned maintenance) dan biaya biaya preventif setiap kejadian (planned maintenance). Tabel IV menunjukkan interval waktu perawatan setiap maintainable item yang diberikan strategi scheduled discard task dan Tabel $\mathrm{V}$ menunjukkan interval waktu perawatan setiap maintainable item yang diberikan strategi scheduled restoration task.

Berikut rumus yang digunakan untuk menghitung biaya korektif dan biaya preventif scheduled discard task:

Total durasi tiap kejadian $=\mathrm{Tde}+\mathrm{Tdc}+\mathrm{Tr}$

$\mathrm{Cu}=\mathrm{Cr}+(\mathrm{Cdt} \mathrm{x}$ total durasi tiap kejadian $)+(\mathrm{Ce} \mathrm{x} \mathrm{Tr})+\mathrm{Ct}$

$\mathrm{Cp}=\mathrm{Cr}+((\mathrm{Cdt}+\mathrm{Ce}) \times \mathrm{Tr})+\mathrm{Ct}$

Berikut rumus yang digunakan untuk menghitung biaya korektif dan biaya preventif scheduled restoration task:

Total durasi tiap kejadian $=\mathrm{Tde}+\mathrm{Tdc}+\mathrm{Trc}$

$\mathrm{Cu}=\mathrm{Crc}+(\mathrm{Cdt} \mathrm{x}$ total durasi tiap kejadian $)+(\mathrm{Ce} \mathrm{x}$ Trc $)+\mathrm{Ct}$

$\mathrm{Cp}=\mathrm{Crc}+((\mathrm{Cdt}+\mathrm{Ce}) \times \mathrm{Trc})+\mathrm{Ct}$

Tde = waktu delay menunggu engineer

Tdc = waktu delay menunggu komponen 
$\operatorname{Tr}=$ waktu penggantian komponen

Trc = waktu restoration komponen

$\mathrm{Cu} \quad=$ Biaya korektif

$\mathrm{Cp} \quad=$ Biaya preventif

$\mathrm{Cr} \quad=$ harga komponen

$\mathrm{Cdt}=$ biaya DT

$\mathrm{Ce}=$ biaya engineer

$\mathrm{Ct} \quad=$ biaya peralatan

Crc = biaya restoration komponen

Berikut rumus untuk menghitung biaya perawatan tiap unit waktu (Cost per Unit Time):

$\operatorname{CPUT}(t)=\frac{C p \cdot R(t)+C u \cdot[1-R(t)]}{\int_{0}^{t} R(s) d s}$

$\mathrm{R}(\mathrm{t})=$ Reliability pada waktu $\mathrm{t}$

$\mathrm{Cp}=$ Biaya preventif (planned maintenance) setiap kejadian

$\mathrm{Cu}=$ Biaya korektif (unplanned maintenance) setiap kejadian

Untuk pengantian item pada interval waktu $\mathrm{t}$ yang optimum dengan biaya perawatan yang paling minimum digunakan rumus berikut ini:

$\frac{\partial[\operatorname{CPUT}(t)]}{\partial t}=0$

TABEL IV

INTERVAL PERAWATAN SCHEDULED DISCARD TASK

\begin{tabular}{|l|l|l|}
\hline $\begin{array}{l}\text { Maintainable } \\
\text { Item }\end{array}$ & Proposed Task & $\begin{array}{l}\text { Interval } \\
\text { (days) }\end{array}$ \\
\hline Gearbox & Scheduled discard task & 155 \\
\hline Sensor & Scheduled discard task & 83 \\
\hline Nozzle & Scheduled discard task & 133 \\
\hline Ejector & Scheduled discard task & 171 \\
\hline Brake & Scheduled discard task & 107 \\
\hline Agitator & Scheduled discard task & 130 \\
\hline Valve & Scheduled discard task & 143 \\
\hline Piston & Scheduled discard task & 232 \\
\hline
\end{tabular}

TABEL V

INTERVAL PERAWATAN SCHEDULED RESTORATION TASK

\begin{tabular}{|l|l|l|}
\hline $\begin{array}{l}\text { Maintainable } \\
\text { Item }\end{array}$ & Proposed Task & $\begin{array}{l}\text { Interval } \\
\text { (days) }\end{array}$ \\
\hline Brake & Scheduled restoration task & 99 \\
\hline Gearbox & Scheduled restoration task & 153 \\
\hline Agitator & Scheduled restoration task & 116 \\
\hline Heater & Scheduled restoration task & 176 \\
\hline Cylinder & Scheduled restoration task & 115 \\
\hline Piston & Scheduled restoration task & 223 \\
\hline Nozzle & Scheduled restoration task & 128 \\
\hline
\end{tabular}

Penentuan interval waktu perawatan scheduled on condition menggunakan P-F interval, $\mathrm{P}$ merupakan titik item yang menunjukkan gejala terjadinya kerusakan sedangkan $\mathrm{F}$ merupakan titik terjadinya kegagalan. Interval waktu perawatan untuk scheduled on condition dihitung berdasarkan rumus berikut:

Interval perawatan on condition $=\frac{1}{2} x P F$ interval $(11)$
Hal ini dilakukan untuk memperketat pemeliharaan mesin dengan pengecekan kondisi mesin untuk meminimasi terjadinya kegagalan fungsional sehingga biaya perawatan lebih rendah karena biaya inventory atau biaya simpan item berkurang. Selain itu juga perhitungan interval perawatan oncondition mempertimbangkan lead time atau waktu pemesanan komponen sampai komponen tersebut masuk ke bagian spare part inventory. Tabel VI menunjukkan interval waktu perawatan setiap maintainable item yang diberikan strategi scheduled on condition.

TABEL VI

INTERVAL PERAWATAN SCHEDULED ON CONDITION

\begin{tabular}{|l|l|l|}
\hline $\begin{array}{l}\text { Maintainable } \\
\text { Item }\end{array}$ & P-F interval (Days) & $\begin{array}{l}\text { Interval Perawatan } \\
\text { (Days) }\end{array}$ \\
\hline Motor & 165 & 83 \\
\hline Brake & 90 & 45 \\
\hline Valve & 106 & 53 \\
\hline Cylinder & 111 & 56 \\
\hline Gearbox & 132 & 66 \\
\hline Piston & 149 & 75 \\
\hline Heater & 151 & 76 \\
\hline
\end{tabular}

Failure finding dilakukan dengan melakukan pengujian fungsi maintenanble item untuk mengetahui apakah item tersebut dapat berfungsi sebagaimana standar operasinya. Biasanya failure finding dilakukan pada item yang berfungsi sebagai protective device dimana item harus dapat beroperasi saat keadaan darurat (emergency) atau redundancy device yang berfungsi sebagai cadangan apabila item active mengalami kerusakan. Perhitungan interval waktu perawatan untuk failure finding yaitu:

$F F I=2 \times$ Unavailability $x M T T F$

Penentuan interval waktu perawatan untuk failure finding bergantung pada criticality item. Semakin item tersebut critical maka item tersebut harus dapat selalu menjalankan fungsinya. Berikut Tabel VII adalah nilai unavailability untuk setiap kategori criticality. Penentuan kategori criticality berdasarkan pada analisis risk matrix.

TABEL VII

UNAVAILABILITY

\begin{tabular}{|c|c|}
\hline \multirow{2}{*}{ Criticality } & Unavailability \\
\hline High & 0.01 \\
\hline Significant & 0.05 \\
\hline Medium & 0.1 \\
\hline Low & 0.3 \\
\hline
\end{tabular}

Berikut adalah perhitungan interval waktu perawatan untuk maintainable item sensor dimana criticality sensor yaitu kategori significant maka unavailability $=0.05$. MTTF sensor yaitu 126.28 hari, sehingga:

Failure finding sensor $=2 \times 0.05 \times 126.28$ hari 


\section{KESIMPULAN}

System Breakdown Structure (SBS) untuk klasifikasi item secara sistematis hingga pada level maintainable item. Maintainable item pada mesin Corazza FF100 terdiri dari motor, brake, valve, cylinder, sensor, gearbox, agitator, piston, nozzle, heater dan ejector.

Maintainable item pada mesin Corazza FF100 berjumlah 27. Berdasarkan metode Reliability Centered Maintenance (RCM) untuk menentukan maintenance task yang sesuai didapatkan 67 maintenance task. Terdapat 17 scheduled discard task, 15 scheduled restoration task, 31 scheduled on condition dan 4 failure finding.

Interval waktu perawatan ditentukan berdasarkan maintenance task yang telah ditentukan menggunakan RCM. Untuk kegiatan perawatan dengan scheduled discard task dan scheduled restoration task perhitungan interval optimal dibantu dengan software Reliasoft RCM++ berdasarkan distribusi TTF, biaya korektif dan biaya preventif. Untuk scheduled on condition, interval perawatan dihitung menggunakan setengah P-F interval. Sedangkan perhitungan interval perawatan failure finding berdasarkan criticality item dan MTTF

Tabel VIII adalah rincian kegiatan perawatan (maintenance task) setiap maintainable item berdasarkan failure mode serta interval waktu perawatannya.

\section{DAFTAR PUSTAKA}

[1] J. Moubray, Reliability Centered Maintenance: RCM II, 2nd ed., Oxford: Butterworth-Heinemann, 1997.

[2] H. S. Wibowati, "Optimasi Kebijakan Perawatan Mesin Kneader KD-75-150D Dengan Menggunakan Metode Reliability Centered Maintenance (RCM II)," 2013.

[3] A. M. Smith, Reliability-Centered Maintenance, McGraw-Hill, 1993.

[4] F. S. Nowlan and H. F. Heap, Reliability-Centered Maintenance, Report Number AD-A066579 ed., Washington, D.C.: Departement of Defense, 1978.

[5] NASA, Reliability-Centered Maintenance Guide For Facilities and Collateral Equipment, National Aeronautics and Space Administration, 2008.

[6] A. C. Márquez, The Maintenance Management Framework: Models and Methods for Complex Systems Maintenance, London: Springer, 2007.

[7] C. E. Ebeling, An Introduction to Reliability and Maintainability Engineering, McGraw-Hill, 1997.

[8] H. Asisco, K. Amar and Y. R. Perdana, "Usulan Perencanaan Perawatan Mesin Dengan Metode Reliability Centered Maintenance (RCM) di PT Perkebunan Nusantara VII (persero) Unit Usaha Sungai Niru Kab. Muara Enim," Kaunia, vol. VIII, no. 2, pp. 7898, 2012.

[9] Naval Surface Warfare Center Carderock Division, "Handbook of Reliability Prediction Procedures for Mechanical Equipment," Maryland, 2011.
[10] ABS, Guidance Notes on Reliability-Centered Maintenance, Houston, TX USA: American Bureau of Shipping, 2004.

[11] ISO 14224:2006, Petroleum and Natural Gas Industries - Collection and Exchange of Reliability and Maintenance Data for Equipment. 2nd Edition. 
TABEL VIII

MAINTENANCE YASK DAN INTERVAL PERAWATAN

\begin{tabular}{|c|c|c|c|c|}
\hline \multicolumn{2}{|c|}{ Item } & Failure Mode & Maintenance Task & $\begin{array}{l}\text { Maintenance } \\
\text { Interval (Days) }\end{array}$ \\
\hline \multirow{6}{*}{$\begin{array}{l}\text { Foil Winding } \\
\text { Subunit } \\
\text { (Body Foil } \\
\text { Unit) }\end{array}$} & \multirow{3}{*}{ Motor } & Panas berlebihan (Overheating) & Scheduled on-condition task (pengecekan suhu motor) & 165 \\
\hline & & Vibrasi & Scheduled on-condition task (pengecekan vibrasi) & 165 \\
\hline & & Overload tripping & $\begin{array}{l}\text { Scheduled on-condition task (pengecekan tegangan listrik } \\
\text { dan kecepatan motor) }\end{array}$ & 165 \\
\hline & \multirow{3}{*}{ Brake } & Low output pressure & Scheduled restoration task (kalibrasi) & 99 \\
\hline & & Aged/heat & Scheduled on-condition task (pengecekan suhu) & 90 \\
\hline & & External leakage & Scheduled discard task (penggantian brake) & 107 \\
\hline \multirow{3}{*}{$\begin{array}{l}\text { Foil Cutting } \\
\text { Subunit } \\
\text { (Body Foil } \\
\text { Unit) }\end{array}$} & \multirow{3}{*}{ Motor } & Panas berlebihan (Overheating) & Scheduled on-condition task (pengecekan suhu motor) & 165 \\
\hline & & Vibrasi & Scheduled on-condition task (pengecekan vibrasi) & 165 \\
\hline & & Overload tripping & $\begin{array}{l}\text { Scheduled on-condition task (pengecekan tegangan listrik } \\
\text { dan kecepatan motor) }\end{array}$ & 165 \\
\hline \multirow{5}{*}{$\begin{array}{l}\text { Foil Cutting } \\
\text { Subunit } \\
\text { (Body Foil } \\
\text { Unit) }\end{array}$} & \multirow{2}{*}{ Valve } & Leakage & $\begin{array}{l}\text { Scheduled on-condition task (pemeriksaan secara visual } \\
\text { pada punggung valve maupun pada seatingnya) }\end{array}$ & 106 \\
\hline & & Gagal membuka dan menutup & Scheduled discard task (penggantian valve) & 143 \\
\hline & \multirow{3}{*}{ Brake } & Low output pressure & Scheduled restoration task (pelumasan) & 99 \\
\hline & & Aged/heat & Scheduled on-condition task (pengecekan suhu) & 90 \\
\hline & & External leakage & Scheduled discard task (penggantian brake) & 107 \\
\hline \multirow{4}{*}{$\begin{array}{l}\text { Wrap Forming } \\
\text { Subunit } \\
\text { (Body Foil } \\
\text { Unit) }\end{array}$} & \multirow{2}{*}{ Cylinder } & Udara keluar (bocor) & $\begin{array}{l}\text { Scheduled on-condition task (pengecekan visual cup } \\
\text { packing) }\end{array}$ & 111 \\
\hline & & Jamming, seizure & $\begin{array}{l}\text { Scheduled restoration task (cleaning filter nipel, } \\
\text { pelumasan) }\end{array}$ & 115 \\
\hline & \multirow{2}{*}{ Sensor } & $\begin{array}{l}\text { Incorrect signal from sensor } \\
\text { element }\end{array}$ & Failure Finding (pengecekan fungsi sensor) & 12 \\
\hline & & loss of signal from sensor element & Scheduled discard task (penggantian sensor) & 83 \\
\hline \multirow{8}{*}{$\begin{array}{l}\text { Cell Turnplate } \\
\text { Unit }\end{array}$} & \multirow{3}{*}{ Motor } & Panas berlebihan (Overheating) & Scheduled on-condition task (pengecekan suhu motor) & 165 \\
\hline & & Vibrasi & Scheduled on-condition task (pengecekan vibrasi) & 165 \\
\hline & & Overload tripping & $\begin{array}{l}\text { Scheduled on-condition task (pengecekan tegangan listrik } \\
\text { dan kecepatan motor) }\end{array}$ & 165 \\
\hline & \multirow{3}{*}{ Brake } & Low output pressure & Scheduled restoration task (kalibrasi) & 99 \\
\hline & & Aged/heat & Scheduled on-condition task (pengecekan suhu) & 90 \\
\hline & & External leakage & Scheduled discard task (penggantian brake) & 107 \\
\hline & \multirow[b]{2}{*}{ Gearbox } & Putaran lemah & Scheduled discard task (penggantian gear) & 155 \\
\hline & & $\begin{array}{l}\text { Missgear atau tidak bersentuhnya } \\
\text { antar gigi pada gearbox }\end{array}$ & Scheduled restoration task (pelumasan) & 153 \\
\hline \multirow{5}{*}{$\begin{array}{l}\text { Hopper } \\
\text { (Filler Unit) }\end{array}$} & \multirow[t]{2}{*}{ Agitator } & $\begin{array}{l}\text { Agitator macet tapi motor } \\
\text { berputar }\end{array}$ & Scheduled discard task (penggantian belt) & 130 \\
\hline & & Agitator tersendat & Scheduled restoration task (pembersihan/cleaning) & 116 \\
\hline & \multirow{3}{*}{ Motor } & Panas berlebihan (Overheating) & Scheduled on-condition task (pengecekan suhu motor) & 165 \\
\hline & & Vibrasi & Scheduled on-condition task (pengecekan vibrasi) & 165 \\
\hline & & Overload tripping & $\begin{array}{l}\text { Scheduled on-condition task (pengecekan tegangan listrik } \\
\text { dan kecepatan motor) }\end{array}$ & 165 \\
\hline \multirow{11}{*}{$\begin{array}{l}\text { Dosing Subunit } \\
\text { (Filler Unit) }\end{array}$} & \multirow[t]{2}{*}{ Valve } & Leakage & $\begin{array}{l}\text { Scheduled on-condition task (pemeriksaan secara visual } \\
\text { pada punggung valve maupun pada seatingnya) }\end{array}$ & 106 \\
\hline & & Gagal membuka dan menutup & Scheduled discard task (penggantian valve) & 143 \\
\hline & \multirow{2}{*}{ Cylinder } & Udara keluar (bocor) & $\begin{array}{l}\text { Scheduled on-condition task (pengecekan visual cup } \\
\text { packing) }\end{array}$ & 111 \\
\hline & & Jamming, seizure & $\begin{array}{l}\text { Scheduled restoration task (cleaning filter nipel, } \\
\text { pelumasan) }\end{array}$ & 115 \\
\hline & \multirow[t]{2}{*}{ Sensor } & $\begin{array}{l}\text { Incorrect signal from sensor } \\
\text { element }\end{array}$ & Failure Finding (pengecekan fungsi sensor) & 12 \\
\hline & & loss of signal from sensor element & Scheduled discard task penggantian sensor) & 83 \\
\hline & \multirow{3}{*}{ Piston } & Leakage & Scheduled restoration task (pelumasan) & 223 \\
\hline & & Keju tidak keluar & Scheduled discard task (penggantian piston) & 232 \\
\hline & & Berisik (Noise) & Scheduled on-condition task (pengecekan suara) & 149 \\
\hline & \multirow[t]{2}{*}{ Nozzle } & Mampet & $\begin{array}{l}\text { Scheduled restoration task (pembersihan/cleaning, } \\
\text { kalibrasi) }\end{array}$ & 128 \\
\hline & & Tekanan nozzle tidak tepat & Scheduled discard task (penggantian nozzle) & 133 \\
\hline
\end{tabular}

Perencanaan Kebijakan Perawatan Mesin Corazza FF100 pada LINE 3 PT XYZ dengan Metode Reliability Centered Maintenance (RCM) II 
TABEL VIII (LANJUTAN)

MAINTENANCE YASK DAN INTERVAL PERAWATAN

\begin{tabular}{|c|c|c|c|c|}
\hline \multicolumn{2}{|c|}{ Item } & Failure Mode & Maintenance Task & $\begin{array}{c}\text { Maintenance Interval } \\
\text { (Days) }\end{array}$ \\
\hline \multirow{6}{*}{$\begin{array}{l}\text { Foil Winding } \\
\text { Subunit } \\
\text { (Top Foil Unit) }\end{array}$} & \multirow{3}{*}{ Motor } & Panas berlebihan (Overheating) & $\begin{array}{l}\text { Scheduled on-condition task (pengecekan } \\
\text { suhu motor) }\end{array}$ & 165 \\
\hline & & Vibrasi & $\begin{array}{l}\text { Scheduled on-condition task (pengecekan } \\
\text { vibrasi) }\end{array}$ & 165 \\
\hline & & Overload tripping & $\begin{array}{l}\text { Scheduled on-condition task (pengecekan } \\
\text { tegangan listrik dan kecepatan motor) }\end{array}$ & 165 \\
\hline & \multirow{3}{*}{ Brake } & Low output pressure & Scheduled restoration task (kalibrasi) & 99 \\
\hline & & Aged/heat & $\begin{array}{l}\text { Scheduled on-condition task (pengecekan } \\
\text { suhu) }\end{array}$ & 90 \\
\hline & & External leakage & Scheduled discard task (penggantian brake) & 107 \\
\hline \multirow{6}{*}{$\begin{array}{l}\text { Foil Cutting } \\
\text { Subunit } \\
\text { (Top Foil Unit) }\end{array}$} & \multirow{3}{*}{ Motor } & Panas berlebihan (Overheating) & $\begin{array}{l}\text { Scheduled on-condition task (pengecekan } \\
\text { suhu motor) }\end{array}$ & 165 \\
\hline & & Vibrasi & $\begin{array}{l}\text { Scheduled on-condition task (pengecekan } \\
\text { vibrasi) }\end{array}$ & 165 \\
\hline & & Overload tripping & $\begin{array}{l}\text { Scheduled on-condition task (pengecekan } \\
\text { tegangan listrik dan kecepatan motor) }\end{array}$ & 165 \\
\hline & \multirow{3}{*}{ Brake } & Low output pressure & Scheduled restoration task (kalibrasi) & 99 \\
\hline & & Aged/heat & $\begin{array}{l}\text { Scheduled on-condition task (pengecekan } \\
\text { suhu) }\end{array}$ & 90 \\
\hline & & External leakage & Scheduled discard task (penggantian brake) & 107 \\
\hline \multirow{4}{*}{$\begin{array}{l}\text { Wrap Forming } \\
\text { Subunit } \\
\text { (Top Foil Unit) }\end{array}$} & \multirow{2}{*}{ Cylinder } & Udara keluar (bocor) & $\begin{array}{l}\text { Scheduled on-condition task (pengecekan } \\
\text { visual cup packing) }\end{array}$ & 111 \\
\hline & & Jamming, seizure & $\begin{array}{l}\text { Scheduled restoration task (cleaning filter } \\
\text { nipel, pelumasan) }\end{array}$ & 115 \\
\hline & \multirow[t]{2}{*}{ Sensor } & $\begin{array}{l}\text { Incorrect signal from sensor } \\
\text { element }\end{array}$ & Failure Finding (pengecekan fungsi sensor) & 12 \\
\hline & & loss of signal from sensor element & Scheduled discard task (penggantian sensor) & 83 \\
\hline \multirow[t]{2}{*}{ Folder Unit } & \multirow[t]{2}{*}{ Sensor } & $\begin{array}{l}\text { Incorrect signal from sensor } \\
\text { element }\end{array}$ & Failure Finding (pengecekan fungsi sensor) & 12 \\
\hline & & loss of signal from sensor element & Scheduled discard task (penggantian sensor) & 83 \\
\hline \multirow{5}{*}{ Press heater } & \multirow{2}{*}{ Cylinder } & Udara keluar (bocor) & $\begin{array}{l}\text { Scheduled on-condition task (pengecekan } \\
\text { visual cup packing) }\end{array}$ & 111 \\
\hline & & Jamming, seizure & $\begin{array}{l}\text { Scheduled restoration task (cleaning filter } \\
\text { nipel, pelumasan) }\end{array}$ & 115 \\
\hline & \multirow{3}{*}{ Heater } & Overheat & $\begin{array}{l}\text { Scheduled on-condition task (pengecekan } \\
\text { suhu heater) }\end{array}$ & 151 \\
\hline & & $\begin{array}{l}\text { Panas tidak rata/seal produk tidak } \\
\text { rata }\end{array}$ & Scheduled restoration task (adjusting) & 176 \\
\hline & & $\begin{array}{l}\text { Temperature heater dan display } \\
\text { tidak cocok }\end{array}$ & Scheduled restoration task kalibrasi) & 176 \\
\hline \multirow{2}{*}{ Pusher Transfer } & \multirow{2}{*}{ Ejector } & Macet (Jammed) & Scheduled discard task (penggantian ejector) & 171 \\
\hline & & Dorongan ejector kurang & Scheduled discard task (penggantian ejector) & 171 \\
\hline
\end{tabular}

